\title{
METODE BOOK TALK UNTUK MENUMBUHKAN KETERAMPILAN BERPIKIR KRITIS DAN KOMUNIKASI EKSPRESIF VERBAL PADA ANAK USIA 3-4 TAHUN
}

\author{
Niko Sudibjo1) \\ Lia Ratna Sagita Tondok2) \\ 1) Universitas Pelita Harapan \\ 2) Sekolah Victory Plus \\ e-mail: niko.sudibjo@uph.edu
}

\begin{abstract}
The 21st century learning trends carry several skills that need to be developed, one of which is critical thinking. The purpose of this study was to analyze the use of the Book Talk method in order to foster critical thinking skills and communicate verbally expressive students aged 3-4 years using Indonesian-themed animal books. This Classroom Action Research was conducted in the Nursery class of Rainbow Victory Plus Bekasi school with the number of research subjects as many as 14 students. Data collection was carried out in 3 cycles held in May 2018. The results of this study showed tha Book Talk method was able to increase critical thinking skills and verbal expressive communication of students. However, it was also found that Book Talk was not suitable for certain types of students.
\end{abstract}

Keywords: critical thinking skills, verbal expressive communication, Book Talk, early childhood

ABSTRAK: Pembelajaran abad ke-21 menuntut keterampilan berpikir kritis dan melakukan komunikasi efektif sebagai syarat keberhasilan. Kemampuan ini perlu dilatih dan diajarkan sejak usia dini. Tujuan penelitian ini adalah untuk menganalisis penggunaan metode Book Talk dalam rangka menumbuhkan keterampilan berpikir kritis dan berkomunikasi ekspresif verbal siswa usia 3-4 tahun dengan menggunakan buku cerita berbahasa Indonesia bertema hewan. Penelitian Tindakan Kelas ini dilakukan di kelas Nursery Rainbow sekolah Victory Plus Bekasi dengan jumlah subjek penelitian 14 siswa. Pengambilan data dilakukan dalam 3 siklus yang dilakukan pada Mei 2018. Hasil penelitian ini menunjukan bahwa metode Book Talk dapat meningkatkan keterampilan berpikir kritis dan berkomunikasi ekspresif verbal siswa. Meskipun demikian, ditemukan juga bahwa Book Talk kurang cocok untuk beberapa tipe siswa tertentu.

Kata kunci: keterampilan berpikir kritis, komunikasi ekspresif verbal, Book Talk, anak usia dini

\section{PENDAHULUAN}

Pendidikan Anak Usia Dini merupakan salah satu sarana penting dalam stimulasi tumbuhkembang anak di masa golden age di mana perkembangan otak seseorang mengalami petumbuhan hingga seukuran $90 \%$ dari ukuran otak dewasa (Fisher 2010, 72). Oleh karena itu, stimulasi yang dilakukan ketika perkembangan di usia dini dipercaya lebih efektif. Lebih lanjut, akal budi yang membedakan manusia dengan makhluk lain memiliki peranan penting dalam kehidupan. Meskipun manusia dan simpanse memiliki DNA yang identik sebanyak 98-99\% (Berk, 2006, 58), akal 
Niko Sudibjo dan Lia Ratna Sagita Tondok - Metode Book

Talk untuk Menumbuhkan Keterampilan Berpikir Kritis dan

Komunikasi Ekspresif Verbal pada Anak Usia 3-4 Tahun

membedakan manusia dengan hewan karena dengan menggunakan akal, manusia tidak semata-mata melakukan suatu tindakan tertentu untuk merespon suatu stimulus tertentu.

Berkaitan dengan pentingnya Pendidikan Anak Usia Dini dan keterampilan berpikir seseorang, peneliti yang merupakan guru kelas kelompok bermain untuk siswa berusia 3-4 tahun di Sekolah Victory Plus dengan kurikulum International Baccalaureate (IB) memilih fokus keterampilan berpikir anak prasekolah untuk diteliti. Dalam kegiatan pembelajaran, ditemukan ketidakmerataan perkembangan kemampuan berpikir siswa yang ditunjukkan oleh keadaan di mana belum semua siswa berpartisipasi pada kegiatan diskusi kelas. Dari segelintir siswa yang mampu menjawab pertanyaan dengan baik, mereka bahkan mampu menjawab pertanyaan dengan tingkat kesulitan tinggi. Namun terdapat juga siswa yang tidak mampu menjawab pertanyaan bahkan dengan tingkat kesulitan mudah sekalipun. Jika terdapat beberapa siswa yang secara konsisten memiliki kemampuan berpikir kritis dan berkomunikasi ekpresif verbal baik, maka sesungguhnya dua keterampilan ini dapat ditumbuhkan melalui stimulasi yang tepat.

Diskusi dalam proses pembelajaran di kelas mempunyai peranan penting dalam proses ikuiri kurikulum IB. Ketika diskusi guru tidak sekedar menyampaikan konten pengetahuan secara searah, tetapi membantu siswa membangun pemahaman sendiri mengenai kompetensi yang dipelajari melalui pertanyaan yang diajukan dan jawaban dari teman maupun guru. Oleh karena itu, pengembangan keterampilan berkomunikasi verbal diperlukan karena siswa yang menguasai keterampilan ini dapat menyampaikan ide dan pendapat dengan jelas, sehingga guru dapat lebih mudah menilai ketercapaian akademis siswa tersebut.

Berdasarkan latar belakang masalah yang telah dibahas sebelumnya, penelitian ini kemudian mengerucut pada 3 rumusan masalah sebagai berikut: 1) Bagaimana proses penerapan metode Book Talk dapat menumbuhkan keterampilan berpikir kritis siswa, 2) Bagaimana metode Book Talk dapat menumbuhkan keterampilan berkomunikasi ekspresif verbal siswa?, dan 3) Kendala apa yang muncul dalam penerapan metode Book Talk.

Pembelajaran menggunakan Book Talk merupakan proses pembacaan buku secara interaktif dan kolaboratif di mana guru tidak hanya membacakan buku cerita bergambar kepada siswa secara satu arah, tetapi juga berusaha membuat siswa memberikan tanggapan dengan menjawab pertanyaan yang diajukan sebagai upaya memahami buku cerita bergambar tersebut dalam semangat kesetaraan (Roche 2015; Wasik et al 2016; Burubules dalam Sutcliffe, 2005).

Terdapat 4 manfaat utama yang didapat dengan memperbincangkan sebuah buku cerita (Roche 2015), yaitu bahwa dalam Book Talk terjadi: 1) pertukaran informasi antar partisipan yang dapat menjadi landasan pengembangan kecerdasan kognitif, 2) pertukaran informasi dalam prinsip kolaboratif dan nonkompetitif mengasah kecerdasan afektif siswa karena siswa saling menghormati dan menghargai perspektif lain, 3) proses tanya jawab yang dapat meningkatkan rasa ingin tahu seorang anak, dan 4) 
Niko Sudibjo dan Lia Ratna Sagita Tondok - Metode Book

dialog yang membantu anak memahami alasan dan makna tentang dunia dan tempat mereka dalam dunia tersebut.

Media yang digunakan dalam Book Talk adalah picture book, yaitu sebuah buku cerita bergambar yang mengandung teks cerita dan ilustrasi berimbang yang berperan sama penting dalam membangun makna yang utuh (American Library Association (ALA) dalam Matulka 2008; Bader dalam Arizpe dan Styles 2003; Roche 2015). Menurut Kiefer dalam Arizpe dan Styles (2003); Nodelman dalam Roche (2015); dan Nurgiyantoro (2005) Terdapat 5 kriteria picture book yang baik yaitu: Memberikan kesenangan bagi pembaca, memiliki tema yang dekat dengan anak, menggunakan bahasa yang sederhana sekaligus kompleks secara seimbang, memiliki ilustrasi yang tidak gamblang menyampaikan pesan serta memiliki pesan moral yang dapat menggugah kesadaran dan hati nurani pembaca.

Ketika menggunakan teknik pembelajaran Book Talk, guru mengajukan pertanyaan untuk menganalisis unsur intrinsik cerita dan ilustrasi. Unsur intrinsik cerita yang dianalisis berupa tema, alur, tokoh, sudut pandang, gaya bahasa, dan amanat (Nurgiyantoro, 2005), sedangkan ilustrasi dianalisis dari segi unsur seni dan desain. Unsur seni berupa warna, garis, perspektif, bentuk, ruang, tekstur, pencahayaan (Matulka, 2008), dan unsur desain meliputi keseimbangan, kontras, penekanan, harmoni, pergerakan, ritme, dan kesatuan.

Keterampilan berpikir kritis adalah kemampuan berpikir tingkat lanjut yang dimiliki oleh seseorang ketika dihadapkan pada proses pengambilan keputusan untuk mencari solusi efektif dengan mempertimbangkan berbagai bukti dan sudut pandang untuk berpikir secara otonom tanpa terpengaruh opini orang lain (Facione dalam Roche, 2015; Roche, 2015; Johnson dalam Harris, 2014; Chesla dan Orr, 2010). Ada beberapa alasan yang mendasari mengapa keterampilan ini perlu dikembangkan pada anak usia dini, yaitu supaya siswa perlu dapat berpikir untuk diri sendiri dan tidak hanya meniru teman sebayanya, terbuka terhadap perbedaan sehingga kepekaan sosialnya menjadi terasah, dapat menyelesaikan masalah sendiri, serta dapat berpikir reflektif untuk memperbaiki diri.

Dalam penelitian ini, indikator keterampilan berpikir kritis yang digunakan untuk mengukur kemampuan anak usia 3-4 tahun adalah sebagai berikut: (1) Menyampaikan pendapat pribadi, (2) Menunjukan kegigihan dalam menyelesaikan masalah, (3) Berani mengajukan masalah, (4) Menemukan persama dan pebedaan akan dua hal tertentu, (5) Pemahaman tentang hubungan sebab akibat.

Dalam Peraturan Menteri nomor 146 tahun 2014, program pengembangan bahasa ekspresif terfokus pada kemampuan siswa mengungkapkan bahasa baik secara verbal dan nonverbal, sementara dalam kurikulum Primary Years Program International Baccalaureat (PYPIB), bahasa ekspresif mirip dengan aspek berbicara (speaking). Adapun indikator keterampilan berkomunikasi ekspresif verbal yang digunakan dalam penelitian ini diambil dari kurikulum PAUD 2013 dan PYPIB untuk anak usia 3-4 tahun yang telah disesuaikan untuk tema transdisipliner Sharing the Planet. Indikator yang dimaksud mencakup: (1) Menggunakan bahasa verbal untuk mengomunikasikan kebutuhan dan atau mengungkapkan ide, (2) Memberi komentar 
atau menjawab pertanyaan untuk menunjukkan pemahaman terhadap buku cerita bergambar yang dibacakan, (3) Menyebutkan nama binatang, (4) Menceritakan cerita pribadi melalui kata-kata, dan (6) Menggunakan kata atau frasa sesuai konteks.

\section{METODE PENELITIAN}

Berdasarkan latar belakang yang telah diuraikan sebelumnya, penelitian ini menggunakan metode Penelitian Tindakan Kelas, yang diharapkan dapat menemukan solusi atas permasalahan yang ada dengan menggunakan 3 siklus pembelajaran, yang berlangsung pada bulan Maret hingga Mei 2018. Siklus pertama terdiri dari 1 pertemuan, siklus kedua dan ketiga masing-masing terdiri dari 2 pertemuan. Terdapat 3 buku cerita bergambar yang digunakan, yakni Odong-odong Dongeng Monyet dan Harimau, Odong-odong Dongeng Bangau dan Rubah, serta Komodo Ingin ke Pesta. PTK ini menggunakan model Kemmis dan McTaggart (Aqib dan Chotibuddin, 2018) di mana setiap siklus memiliki 4 langkah yaitu: 1) Perencanaan tindakan (planning); 2) Pelaksanaan tindakan (acting); 3) Pengamatan (observing); 4) Refleksi (reflecting). Perencanaan alokasi waktu untuk setiap siklus adalah 1 X 30 menit. Adapun subjek penelitian terdiri dari 14 siswa, 9 perempuan dan 5 laki-laki berusia 45-53 bulan di kelas Nursery Rainbow Sekolah Victory Plus Bekasi.

Instrumen penelitian yang digunakan adalah rubrik, catatan lapangan, lembar wawancara dan video. Data dikumpulkan melalui observasi saat tindakan pembacaan cerita dan wawancara pasca pembacaan cerita dengan panduan rubrik yang telah disusun yang memuat indikator keterampilan berpikir kritis dan berkomunikasi ekspresif verbal. Untuk membantu pengamatan agar lebih akurat digunakan rekaman video untuk menganalisis sikap dan respons siswa dan peneliti pada saat tindakan dilakukan. Selain itu, digunakan catatan lapangan untuk mencatat hal-hal lain yang tidak tergambar pada instrumen lain.

\section{HASIL DAN PEMBAHASAN}

Sekolah Victory Plus (SVP) adalah sekolah umum dengan visi membentuk komunitas pembelajar sepanjang hayat, warga dunia dan entrepreneurs yang peduli dan bertanggung jawab. Sekolah ini melayani peserta didik mulai dari usia 6 bulan di kelas Baby Gym, hingga usia 18 tahun di kelas 12. SVP memiliki 125 orang guru dengan total jumlah siswa 952. Pada jenjang PAUD, terdapat 30 guru dengan 225 siswa. Sebagian besar orang tua siswa PAUD SVP berprofesi beragam mulai dari pegawai negeri, karyawan swasta, kaum profesional, wiraswasta, dan ibu rumah tangga.

Dalam penelitian ini, data demografis siswa yang digunakan adalah tanggal kelahiran, usia, jenis kelamin, dan bahasa yang digunakan sehari-hari. Pada awalnya, subjek penelitian terdiri dari 14 siswa. Data perkembangan ketrampilan berpikir kritis keempat belas siswa tersebut dipaparkan dalam Tabel 1.

Berdasarkan observasi kelas dan wawancara dengan guru ditemukan ketidakmerataan kemampuan berpikir kritis dan berkomunikasi ekspresif verbal di kelas Nursery Rainbow. Dari 14 siswa, terdapat 6 siswa yang memiliki kemampuan berpikir 
kritis baik, yaitu $F, H, D, M, L$, dan $C$. Selain itu, terdapat 4 siswa berkemampuan cukup, yakni E, G, I, dan N. Kemudian terdapat 4 siswa berkemampuan kurang, yaitu $\mathrm{B}, \mathrm{K}, \mathrm{J}$, dan $\mathrm{O}$. Sementara itu, dalam keterampilan berkomunikasi ekspresif verbal, terdapat 5 siswa dalam kategori baik, yaitu F, D, C, H, dan G. Sedangkan 6 siswa memiliki keterampilan berkomunikasi eskpresif verbal cukup, yakni $E, M, I, J, L, N$. Kemudian terdapat 3 siswa dengan kemampuan kurang, yaitu $B, K, O$.

\begin{tabular}{ccccc}
\multicolumn{5}{c}{ Tabel 1. Perkembangan Keterampilan Berpikir Kritis Siklus } \\
\hline No & Nama & Siklus 1 & Siklus 2 & Siklus 3 \\
\hline 1 & B & 25 & 35 & 40 \\
2 & C & 60 & 45 & 80 \\
3 & D & 70 & 65 & 85 \\
4 & E & 55 & 55 & 70 \\
5 & F & 85 & 80 & 75 \\
6 & G & 40 & 55 & 70 \\
7 & H & 65 & 65 & 75 \\
8 & I & 70 & 65 & 75 \\
9 & J & 55 & 55 & 90 \\
10 & K & 30 & 30 & 45 \\
11 & L & 70 & 65 & 80 \\
12 & M & 65 & 65 & 50 \\
13 & N & 60 & 55 & 80 \\
14 & O & 45 & 60 & 80 \\
\hline
\end{tabular}

Pada siklus 3 ditemukan bahwa tiga siswa dengan keterampilan berpikir kritis yang paling rendah, yaitu $\mathrm{B}, \mathrm{K}$, dan $\mathrm{O}$ mengalami kenaikan secara konsisten, walaupun untuk $\mathrm{B}$ dan $\mathrm{K}$ masih dalam klasifikasi sangat kurang yakni di bawah $60 \%$. Hal ini disebabkan oleh keterlambatan perkembangan produksi bahasa $\mathrm{B}$ dan perkembangan kognitif $\mathrm{K}$ jika dibandingkan dengan tahapan perkembangan anak usia 3-4 tahun, terutama dalam memahami hubungan sebab akibat. Sedangkan 0 yang sebelumnya memiliki nilai rendah mengalami kenaikan cukup banyak senilai $35 \%$. Selain itu $\mathrm{J}$ mencapai perkembangan sebesar $35 \%$, bahkan ia meraih nilai tertinggi jika dibandingkan dengan siswa lain. Dalam kasus $O$ yang pemalu dan $\mathrm{J}$ yang memiliki kendala berbahasa Inggris, penerapan metode Book Talk dengan buku cerita bergambar dalam bahasa Indonesia dapat membantu perkembangan keterampilan berpikir kritisnya.

Terdapat 1 siswa yang mengalami penurunan dari siklus 2 ke siklus 3 sebesar $15 \%$, yaitu M karena tidak menunjukkan ketertarikan pada pembacaan cerita dalam bahasa Indonesia. Hal ini sejalan dengan temuan hasil wawancara dengan orang tua $\mathrm{M}$ yang menyatakan bahwa kasus penolakan terhadap Bahasa Indonesia, bahasa yang digunakan selama tindakan $\mathrm{M}$ juga terjadi pada kakak perempuannya yang memiliki 
kesulitan dalam pelajaran Bahasa Indonesia hingga kelas 3 SD. Hal ini disebabkan oleh bahasa Inggris yang lebih sering digunakan di rumah mereka.

\section{Keterampilan Berkomunikasi Ekspresif Verbal Pasca Intervensi}

Pada umumnya, terdapat kenaikan hasil keterampilan berkomunikasi ekspresif verbal dari siklus 1 hingga siklus 3. Meskipun demikian terdapat 3 siswa yang memiliki kesulitan menggunakan kata sesuai konteks, yaitu B, K, dan M. M dapat menceritakan cerita pribadi dengan lebih lancar jika dibandingkan sebelum intervensi. Namun, cerita yang disampaikannya masih belum sesuai konteks. Sedangkan B dan M masih memiliki kesulitan merespons secara verbal sesuai konteks karena untuk $B$ yang pemalu dan memiliki keterbatasan wicara, ia masih belum terbiasa sehingga ia perlu menyesuaikan responsnya yang sebelumnya cukup hanya dengan bahasa non verbal atau mengatakan kata tunggal yang bersifat hapalan. $M$ yang lebih lancar berbahasa Inggris dibandingkan bahasa Indonesia juga memiliki minat yang sempit. Hal ini sesuai dengan pernyataan orang tua M pada saat wawancara pasca PTK yang mengatakan bahwa kasus yang sama juga terjadi pada kakak perempuan $M$ yang memiliki nilai Bahasa Indonesia kurang hingga kelas 3 SD karena kakak M tidak berminat pada Bahasa Indonesia.

Sementara itu terdapat 2 siswa yang mencapai nilai 100 untuk keterampilan berkomunikasi verbal karena $L$ yang sebelum intervensi memiliki kemampuan pengungkapan bahasa rata-rata, mampu menganalisis perspektif ilustrasi yang sangat maju yang menunjukkan perkembangan keterampilan berkomunikasi eskpresif verbalnya secara konsisten. Sedangkan $D$ yang mendapat nilai sangat baik lainnya, mampu mengungkapkan ide melalui penggunaan kata sesuai konteks secara konsisten. Perkembangan keterampilan berkomunikasi ekspresif verbal seluruh siswa selama siklus dapat dilihat dalam tabel 2 sebagai berikut:

Tabel 2. Perkembangan Keterampilan Berkomunikasi Ekspresif Verbal Siklus 1-3

\begin{tabular}{ccccc}
\hline No & Nama & Siklus 1 & Siklus 2 & Siklus 3 \\
\hline 1 & B & 25 & 25 & 55 \\
2 & C & 80 & 80 & 95 \\
3 & D & 90 & 95 & 100 \\
4 & E & 90 & 75 & 80 \\
5 & F & 85 & 100 & 95 \\
6 & G & 65 & 65 & 95 \\
7 & H & 75 & 70 & 80 \\
8 & I & 70 & 80 & 90 \\
9 & J & 55 & 50 & 95 \\
10 & K & 40 & 45 & 60 \\
11 & L & 65 & 85 & 100 \\
12 & M & 50 & 60 & 55 \\
13 & N & 55 & 65 & 80 \\
14 & O & 70 & 65 & 75 \\
\hline
\end{tabular}




\section{Analisis dan Temuan Setiap Siklus \\ Siklus 1}

Dalam siklus 1, meskipun rencana telah disusun dengan baik, sesuai teori Roche mengenai Book Talk, pada kenyataannya, banyak hal yang terjadi di lapangan tidak sesuai harapan sehingga diperlukan fleksibilitas peneliti.

Dalam siklus 1 siswa belum dapat mengenali prinsip unsur seni dan desain karena ketika ditanya tentang ilustrasi yang menggambarkan beberapa monyet di halaman 3, para siswa mengatakan bahwa terdapat banyak monyet dan bukan satu monyet yang sedang meloncat dari atas dahan ke tanah. Namun yang mengejutkan adalah ketika ditanya apa yang dapat dilakukan oleh Monyet agar terbebas dari Harimau yang terus menerus menyuruhnya bekerja di rumah Harimau, D yang seperti siswa lain yang menganggap terdapat beberapa monyet di dalam cerita mengusulkan solusi prinsip bekerja dalam giliran, di mana ketika satu monyet menyapu, yang lain duduk dahulu untuk kemudian bergantian bekerja pada saat gilirannya masing-masing. llustrasi tersebut dapat dilihat dalam Gambar 1.

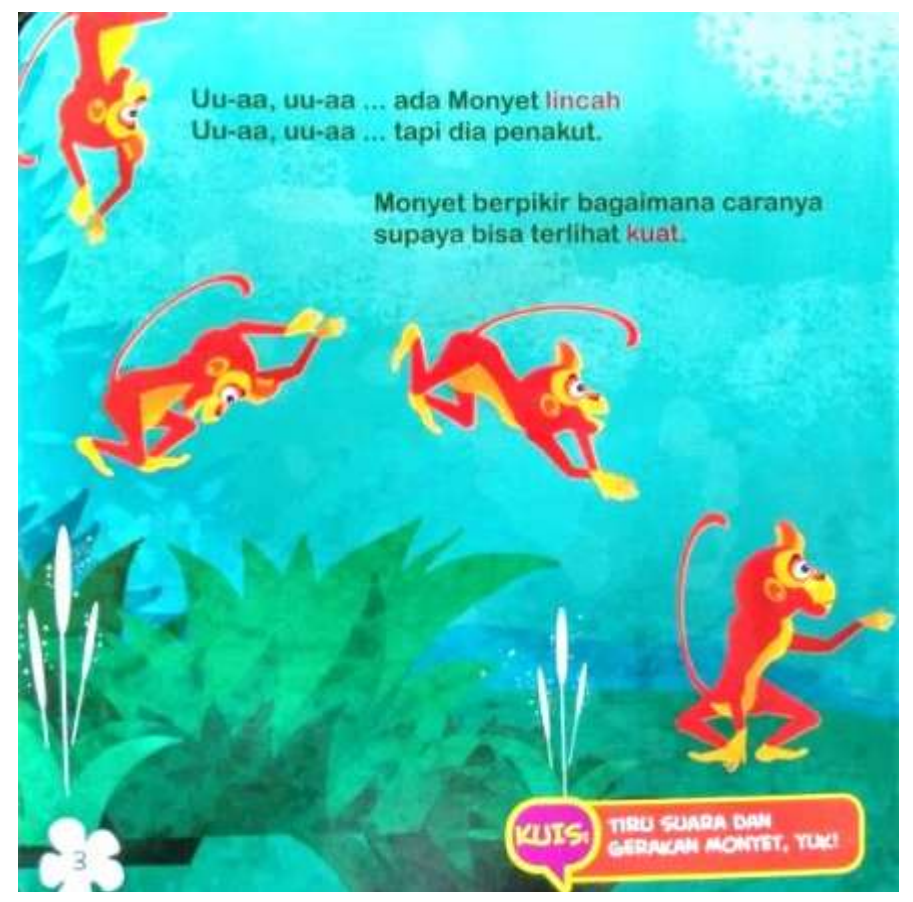

Gambar 1. Cuplikan Buku Harimau dan Monyet (halaman 3)

\section{Siklus 2}

Dalam siklus 2, pemusatan perhatian siswa sudah lebih baik dengan durasi pembacaan cerita yang diperpendek. Secara umum, berdasarkan observasi dan wawancara yang dilakukan dalam kelompok kecil beranggotakan 3 orang, terdapat peningkatan performa keterampilan berpikir kritis dan berkomunikasi ekpresif verbal. 
Hal ini terutama terlihat dari pencapaian $\mathrm{B}, \mathrm{K}, \mathrm{O}$, tiga siswa dengan nilai terendah. $\mathrm{O}$ yang sesungguhnya memiliki keterampilan berpikir kritis dan berkomunikasi ekpresif verbal baik, tetapi pemalu dan tidak percaya diri berinteraksi dalam bahasa Inggris, dapat memberikan pengaruh baik pada perkembangan dua keterampilan ini di diri $B$ dan $\mathrm{K}$ melalui jawaban-jawaban yang diberikan saat wawancara dalam kelompok kecil.

Di pertemuan kedua dengan bantuan visualizer, I yang kerap teralihkan perhatiannya mampu memperhatikan detail emosi pada raut wajah Rubah yang kesal karena tidak mampu memakan biji-bijian yang disuguhkan di dalam botol oleh Rubah. I mengatakan bahwa Rubah marah. Ekspresi kesal ditunjukkan Rubah melalui penggunaan garis melengkung ke bawah untuk alis Rubah. Ilustrasi tersebut dapat dilihat dalam Gambar 2.

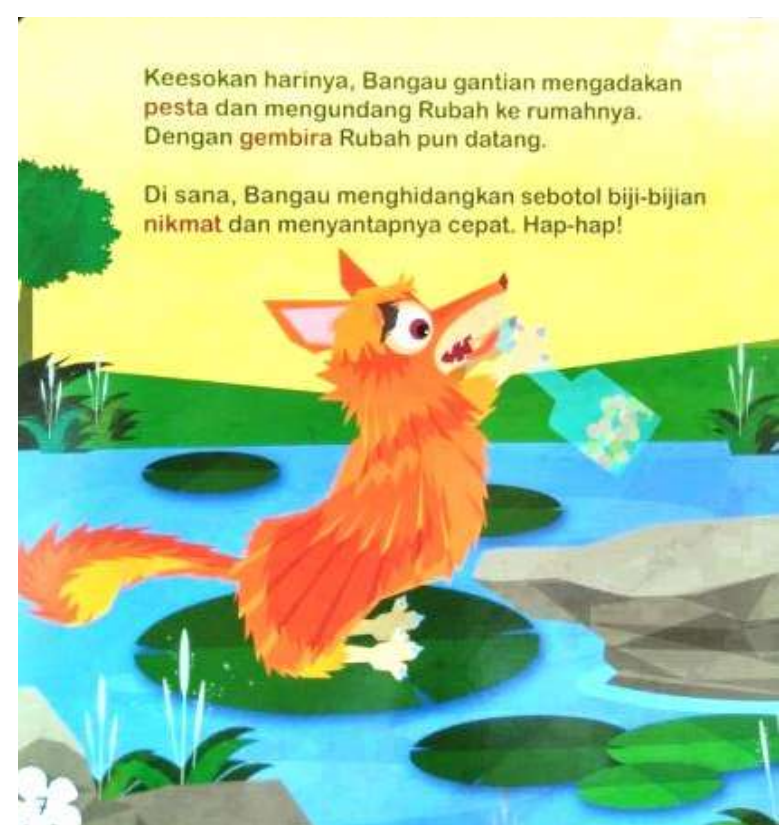

Gambar 2. Cuplikan Buku Bangau dan Rubah (halaman 7)

\section{Siklus 3}

Pada siklus 3 terdapat inkonsistensi pertumbuhan performa siswa secara keseluruhan di mana tiga siswa dengan pencapaian terendah $\mathrm{B}, \mathrm{K}, \mathrm{O}$ mengalami peningkatan, sedangkan $\mathrm{F}$ dan $\mathrm{M}$ yang memiliki performa baik sebelumnya mengalami penurunan. Hal ini dapat disebabkan oleh beberapa faktor, meskipun secara umum, antuasisme siswa meningkat dengan dilakukan Tepuk Komodo. Pertama, F merasa bosan dan tidak percaya diri ketika diwawancarai seorang diri. Kedua, M yang memiliki keterbatasan pengungkapan bahasa memiliki minat yang lebih baik terhadap pembacaan cerita dalam bahasa Inggris, dibandingkan dengan yang dibacakan dalam bahasa Indonesia. Adapun siswa pada umumnya merasa lebih percaya diri untuk mengungkapkan ide pribadi karena mereka tidak takut membuat kesalahan. Dalam 
Book Talk segala jawaban yang memiliki alasan penalaran yang relevan dapat diterima dalam diskusi.

Selain itu di siklus 3, siswa lebih peka dalam menganalisis detail ilustrasi yang mengenali fungsi penggunaan warna cerah dan kelam untuk menggambarkan karakter baik dan buruk. D mengatakan Ora Komodo jahat karena berwarna kelabu. Sedangkan F mampu menemukan paradoks dengan mengatakan bahwa Ora yang di sampul depan adalah tokoh antagonis sedangkan Ora di halaman 18 yang berwarna cerah setelah dicat dan dipersolek dengan busana dan aksesoris adalah tokoh protagonis. llustrasi tersebut dapat dilihat dalam Gambar 3a dan 3b.

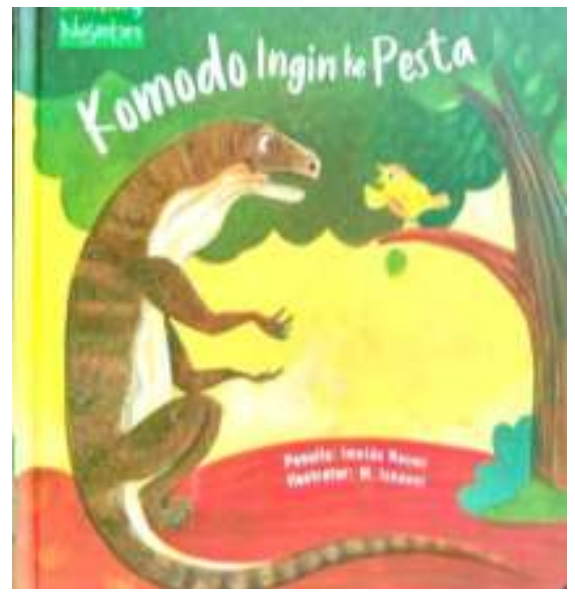

Gambar 3a. Cuplikan Buku Komodo Ingin ke Pesta Perwatakan

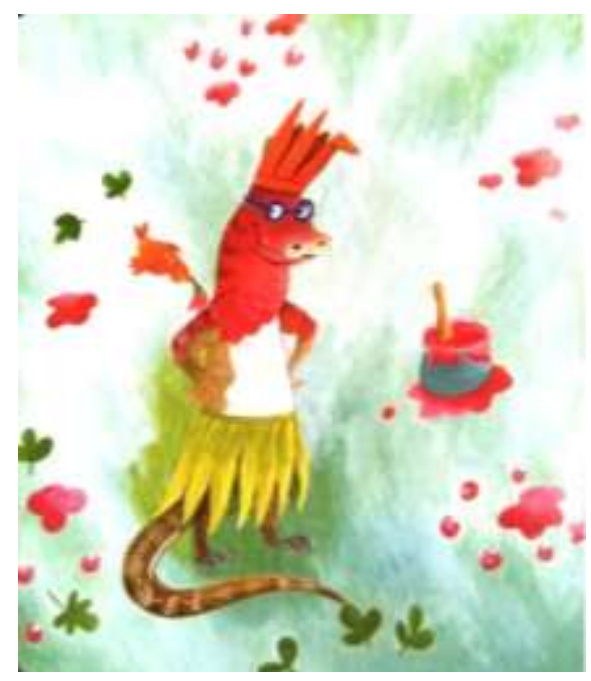

Gambar 3b. Cuplikan Buku Komodo Ingin ke Pesta Perwatakan 
Selain itu, beberapa siswa seperti $L$ dan $F$ dapat menginterpretasikan elemen garis untuk menggambarkan adanya angin yang berhembus dan menggerakkan dedaunan. Ilustrasi tersebut dapat dilihat dalam Gambar 4a dan 4b.

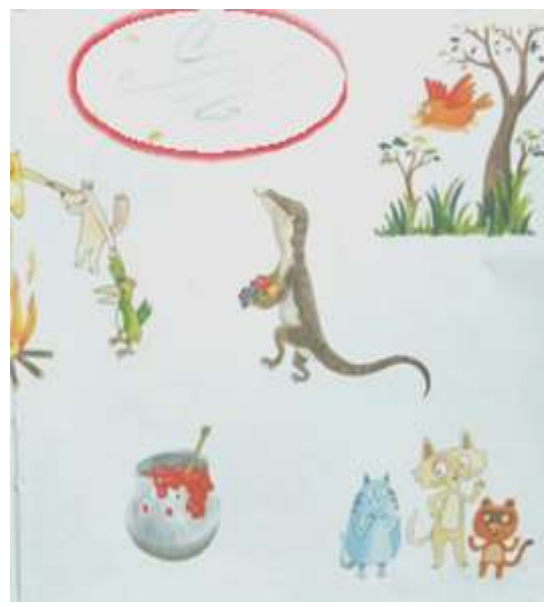

Gambar 4a. Cuplikan Buku Komodo Ingin ke Pesta Analisis Unsur Seni dan Desain

Selain itu, pengamatan tajam terhadap detail ilustrasi juga ditunjukkan oleh $\mathrm{M}$. Meskipun tidak konsisten, secara mengejutkan $\mathrm{M}$ dapat mengenali fokus interaksi antara Ora Komodo yang mendongak dan Burung Koak Kiau yang berada di atas pohon sedang berbincang. Perspektif sudut pandang normal membuat fokus adegan lebih jelas berpusat di interaksi mereka.

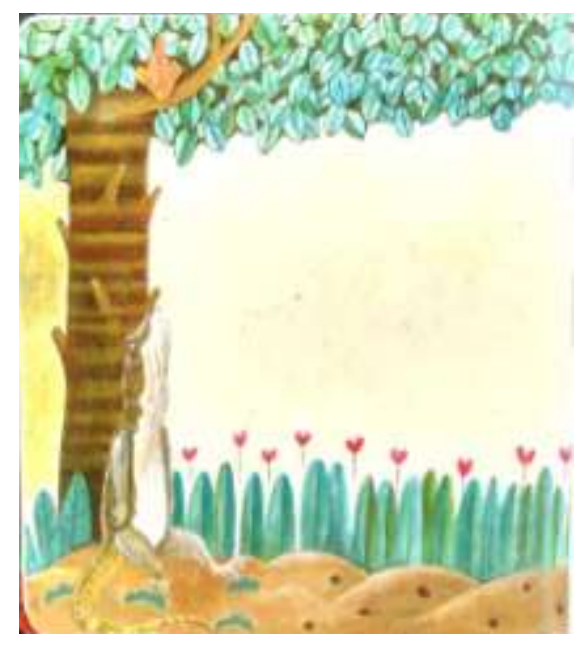

Gambar 4b. Cuplikan Buku Komodo Ingin ke Pesta Analisis Unsur Seni dan Desain (halaman 6) 
Lebih lanjut, L mampu mengidentifikasi binatang ular yang dilingkari dalam Gambar 4.5a, sesuatu yang disangka binatang ajaib rekaan ilustrator semata. Selain itu, $\mathrm{L}$ dan $\mathrm{J}$ mampu mengenali perbedaan perspektif antar tokoh. Mereka berkata bahwa dalam gambar tersebut mereka tidak dapat melihat Ora Komodo karena ia berada di depan hewan-hewan hutan lain yang tergambar di ilustrasi tersebut yang dapat dilihat dalam Gambar 5a.

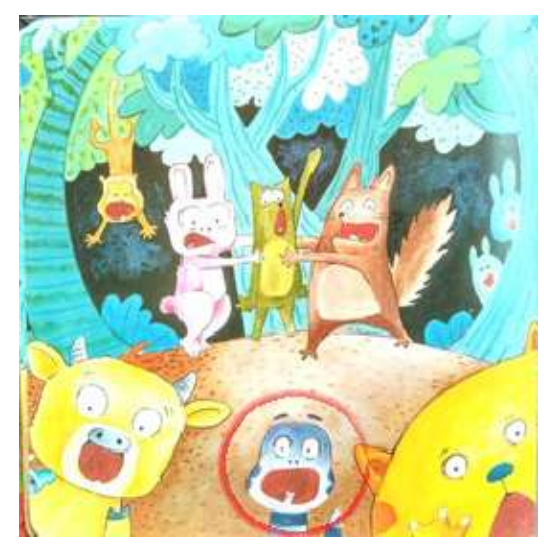

Gambar 5a. Cuplikan Buku Komodo Ingin ke Pesta Perspektif (halaman 14)

Perbedaan perspektif juga dikenali oleh I yang mempertanyakan mengapa Koak Kiau yang lebih kecil terlihat lebih besar di halaman 28 dan mengapa hewan hutan lain terlihat lebih kecil dan dalam posisi terbalik. Hal ini sesungguhnya disebabkan oleh penggambaran ilustrasi dari sudut pandang pohon. llustrasi tersebut dapat dilihat dalam Gambar 5b.

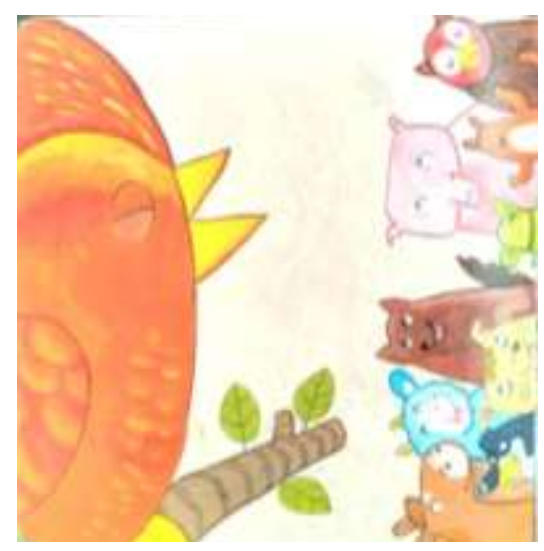

Gambar 5b. Cuplikan Buku Komodo Ingin ke Pesta

Perpektif (halaman 28) 
yaitu:

Pada akhirnya penelitian ini dihentikan pada siklus 3 karena beberapa faktor,

a. Terdapat indikasi kebosanan pada siswa yang memiliki keterampilan berpikir kritis dalam kategori baik dan sangat baik sehingga mempengaruhi penurunan pencapaian indikator keterampilan tersebut. Ketika tindakan dilanjutkan dalam siklus berikutnya dikhawatirkan penurunan ini akan semakin memburuk.

b. Tiga siswa yang memiliki keterampilan berpikir kritis sangat kurang memiliki permasalahan keterlambatan wicara, keterlambatan perkembangan kognitif dan ketiadaan minat terhadap bahasa Indonesia. Bukan sekedar permasalahan sifat pemalu atau kendala bahasa pengantar yang teridentifikasi dalam masa pra siklus. Permasalahan yang dialami ketiga siswa tersebut perlu diatasi sebelum mereka siap diintervensi dengan metode Book Talk.

c. Meskipun lebih dari $50 \%$ siswa memiliki keterampilan berpikir kritis dalam kategori sangat kurang dan kurang secara keseluruhan dalam 5 indikator berpikir kritis yang telah dirumuskan, lebih dari 50\% siswa bernilai baik dan sangat baik dalam 3 indikator penting, yaitu: menyampaikan pendapat pribadi tanpa meniru orang lain, menunjukkan persamaan atau perbedaan, dan menunjukkan pemahaman terhadap hubungan sebab akibat.

d. Terdapat nurturing effect berupa peningkatan rasa percaya diri siswa yang memenuhi harapan peneliti. Setelah tindakan, semua siswa tidak sungkan untuk menjawab pertanyaan padahal sebelum siklus 1, peneliti kerap merasa berbicara dengan dinding karena ketiadaan respons verbal dari siswa yang sesuai harapan.

\section{Kendala Penerapan Metode Book Talk dan Solusinya}

Dalam implementasi metode Book Talk untuk menumbuhkan keterampilan berpikir kritis dan berkomunikasi ekpresif verbal siswa Nursery Rainbow, ditemukan beberapa kendala yang dijabarkan dengan lebih rinci dalam Tabel 3.

Tabel 3. Kendala dan Cara Mengatasinya

\begin{tabular}{|c|c|c|c|}
\hline No & Aspek & Kendala & Cara Mengatasi \\
\hline a. & Prinsip dialogis & $\begin{array}{l}\text { Siswa tidak perlu bergiliran } \\
\text { menyampaikan pendapat sehingga } \\
\text { siswa berbicara bersamaan dan } \\
\text { menimbulkan kebisingan karena } \\
\text { mereka menaikan suara mereka } \\
\text { agar terdengar. } \\
\text { Selain itu, siswa dominan kerap } \\
\text { memonopoli aktivitas diskusi. }\end{array}$ & $\begin{array}{l}\text { - Peneliti meminta siswa mengangkat } \\
\text { tanggannya sebelum berbicara pada } \\
\text { siklus } 2 \text { pertemuan } 1 \\
\text { - Peneliti memberi kesempatan kepada } \\
\text { siswa pemalu dengan memanggil } \\
\text { namanya untuk menyampaikan } \\
\text { pendapat dan menjawab pertanyaan }\end{array}$ \\
\hline b. & $\begin{array}{l}\text { Bahasa } \\
\text { pertanyaan }\end{array}$ & $\begin{array}{l}\text { Peneliti menyusun pertanyaan } \\
\text { dengan tingkat kesulitan sesuai } \\
\text { taksonomi Bloom dengan sangat } \\
\text { rinci tetapi tidak disesuaikan dengan } \\
\text { indikator keterampilan berpikir kritis } \\
\text { dan berkomunikasi ekspresif verbal }\end{array}$ & $\begin{array}{l}\text { Peneliti menyusun pertanyaan dengan } \\
\text { mempertimbangkan indikator yang } \\
\text { utama, lalu Taksonomi Bloom dan } \\
\text { kesesuaian tema buku cerita } \\
\text { selanjutnya. }\end{array}$ \\
\hline
\end{tabular}


Tabel 3. Lanjutan

\begin{tabular}{|c|c|c|c|}
\hline No & Aspek & Kendala & Cara Mengatasi \\
\hline c. & $\begin{array}{l}\text { Jawaban tidak } \\
\text { terduga dari } \\
\text { siswa }\end{array}$ & $\begin{array}{l}\text { Jawaban dan partisipasi siswa sering } \\
\text { tidak terduga ke mana arahnya dan } \\
\text { dalam Book Talk tidak ada satu } \\
\text { jawaban mutlak benar karena } \\
\text { interpretasi siswa dapat berbeda- } \\
\text { beda dan semua benar adanya. }\end{array}$ & $\begin{array}{l}\text { - Peneliti menyiapkan alternatif } \\
\text { pertanyaan yang beragam. } \\
\text { - Peneliti fleksibel dan memanfaatkan } \\
\text { momen untuk mengembangkan } \\
\text { diskusi. } \\
\text { - Peneliti fokus pada daftar pertanyaan } \\
\text { yang disusun. }\end{array}$ \\
\hline d. & $\begin{array}{l}\text { Waktu sekolah } \\
\text { terbatas hanya } \\
2 \text { jam }\end{array}$ & $\begin{array}{l}\text { - Peneliti memiliki target akademis } \\
\text { lain yang perlu dicapai. } \\
\text { - Peneliti berbagi waktu dengan } \\
\text { guru pelajaran lain. } \\
\text { - Kegiatan akhir semester yang } \\
\text { cukup padat. }\end{array}$ & $\begin{array}{l}\text { - Peneliti memasukkan pokok bahasan } \\
\text { pelajaran lain dalam wawancara } \\
\text { dengan siswa. } \\
\text { - Wawancara siswa tidak hanya } \\
\text { dilakukan saat istirahat makan, tetapi } \\
\text { juga ketika pelajaran lain dengan } \\
\text { sistem rotasi. }\end{array}$ \\
\hline e. & $\begin{array}{l}\text { Keterbatasan } \\
\text { buku bercerita } \\
\text { bergambar } \\
\text { berbahasa } \\
\text { Indonesia } \\
\text { berkualitas dan } \\
\text { sesuai tema. }\end{array}$ & $\begin{array}{l}\text { Buku cerita bergambar dengan isi } \\
\text { cerita dan ilustrasi menarik yang } \\
\text { sesuai dengan kriteria masih sangat } \\
\text { terbatas jumlahnya. }\end{array}$ & $\begin{array}{l}\text { - Peneliti menggunakan visualizer agar } \\
\text { siswa dapat melihat ilustrasi lebih } \\
\text { jelas pada pertemuan } 2 \text { siklus } 2 \text {. } \\
\text { - Diskusi dilakukan tidak dalam posisi } \\
\text { lingkaran melainkan guru duduk di } \\
\text { kursi agar siswa dapat melihat buku } \\
\text { dengan lebih baik lagi pada } \\
\text { pertemuan } 2 \text { siklus } 3 \text {. }\end{array}$ \\
\hline f. & $\begin{array}{l}\text { Fokus siswa } \\
\text { yang masih } \\
\text { pendek }\end{array}$ & $\begin{array}{l}\text { Diskusi yang terlalu lama menjadi } \\
\text { kurang efektif karena fokus siswa } \\
\text { teralihkan pada hal lain yang kurang } \\
\text { konstruktif. }\end{array}$ & $\begin{array}{l}\text { Peneliti melakukan Book Talk pada saat } \\
\text { wawancara dengan siswa mulai dari } \\
\text { siklus } 2 \text { dan tidak pada saat pembacaan } \\
\text { cerita karena siswa tidak sabar dan } \\
\text { lebih tertarik mendengarkan cerita } \\
\text { dibandingkan dengan kegiatan } \\
\text { berdiskusi itu sendiri. }\end{array}$ \\
\hline
\end{tabular}

\section{Keterbatasan Penelitian}

Keterbatasan dalam penelitian ini adalah hasil penelitian bersifat eksklusif karena subjek penelitian hanya 14 anak yang berasal dari 1 kelas dengan hanya melibatkan 1 guru kelas saja. Oleh sebab itu, penelitian ini tidak dapat digeneralisasi pada kondisi kelas lain. Keterbatasan selanjutnya adalah bahwa konteks penelitian terbatas pada pembacaan buku cerita bergambar bertema binatang dan wawancara yang keduanya dilakukan dalam bahasa Indonesia.

\section{KESIMPULAN DAN SARAN Kesimpulan}

Berdasarkan hasil dan pembahasan yang sudah dipaparkan sebelumnya, maka dapat disimpulkan bahwa proses penerapan metode Book Talk perlu disesuaikan agar dapat menumbuhkan keterampilan berpikir kritis anak usia dini. Selanjutnya, metode Book Talk yang telah disesuaikan juga dapat menumbuhkan keterampilan 
berkomunikasi ekspresif verbal siswa pada umumnya. Meskipun demikian, metode ini membutuhkan percakapan intens antar partisipan yang tidak cocok untuk semua tipe siswa. Kesimpulan yang terakhir adalah meskipun terdapat beberapa kendala dalam penerapan metode Book Talk, secara umum kendala ini dapat diatasi dengan fleksibilitas dan kepiawaian guru membaca situasi di kelas anak prasekolah.

\section{Saran}

Berdasarkan refleksi implementasi Book Talk di lapangan, peneliti memiliki beberapa masukan untuk penerapan metode ini dan penelitian selanjutnya. Pertama, disebabkan oleh fokus siswa yang masih pendek, guru perlu memilah beberapa pertanyaan yang penting dan terfokus serta diatur derajat kesulitannya seiiring bertambahnya waktu penerapan metode ini. Kedua, sebaiknya siswa setidaknya diwawancarai berdua-dua, dan tidak sendiri-sendiri untuk mencegah rasa gugup seperti menghadapi ujian. Selain itu, pengelompokan siswa yang aktif dan pemalu perlu dikombinasikan dalam beberapa kali pertemuan wawancara. Ketiga, metode Book Talk dapat juga digunakan untuk menumbuhkan kemampuan kosakata bahasa Inggris bagi siswa berbahasa ibu Indonesia karena siswa dapat belajar kata-kata bahasa asing baru yang tidak dijumpai dalam kehidupan sehari-hari. Ke-empat, metode Book Talk dapat digunakan untuk mengembangkan literasi visual karena siswa usia dini dapat memahami gambar dengan perspektif baru yang terkadang tidak dipahami oleh orang dewasa. Kelima, dapat dilakukan penelitian lanjutan pasca penelitian ini yang bersifat longitudinal untuk mengukur pencapaian kesiapan sekolah siswa setelah intervensi, di tingkat pendidikan selanjutnya. Ke-enam, berdasarkan hasil penelitian ini terlihat peningkatan minat baca dan kepercayadirian siswa dalam mengungkapkan ide yang dapat diteliti lebih lanjut.

\section{REFERENSI}

Arizpe, E., \& Styles, M. (2003). Children Reading Pictures: Interpreting Visual Texts. London: Routledge Falmer.

Aqib, Z., \& Chotibuddin, M. (2018). Teori dan Aplikasi Penelitian Tindakan Kelas. Yogyakarta: Deepbulish.

Berk, L. E. (2006). Child Development. Boston: Pearson.

Chesla, E., \& Orr, T. (2010). Reasoning Skills Success In 20 Minutes A Day. New York: Learning Express.

Fisher, R. (2010). Teaching Thinking in the Classroom. London: Bloomsbury.

Harris, B. (2014). Creating A Classroom Culture That Supports The Common Core: Teaching Questioning, Conversation Techniques, And Other Essential Skils. New York: Routledge.

Matulka, D. I. (2008). A Picture Book Primer: Understanding and Using Picture Books. Westport: Libraries Unlimited.

Nurgiyantoro, B. (2005). Sastra Anak: Pemahaman Dunia Anak. Yogyakarta: Gadjah Mada University Press. 
Roche, M. (2015). Developing Children's Critical Thinking through Picturebooks: A Guide for Primary and Early Years Students and Teachers. Oxon: Routledge.

Sutcliffe, R. (2005). Reasons and Supporting Evidence for The Benefits of Practising Dialogue in the Classroom. In J. Giordmaina, R. Sutcliffe, R. Bartels, Z. C. Moura, F. G. Moriyón, I. Rocena, H. Juuso, Dialogue On Dialogue: A Resource Book For The Developing Dialogue Through Philosophical Enquiry Course For Teachers (pp. 26-54). United Kingdom: nk.oulu.fi.

Wasik, B. A., Hindman, A. H., \& Snell, E. K. (2016). Book reading and vocabulary development: A systematic review. Early Childhood Research Quarterly 37, 3957 . 